\title{
O encontro da militância com a vadiagem nas prisóes da Ilha Grande
}

\author{
Myrian Sepulveda Santos*
}

\section{RESUMO}

A partir do estudo sobre prisóes da Ilha Grande na primeira metade do século XX, este artigo investiga a construção de uma cultura punitiva que criminalizou grupos sociais que se encontravam em condiçôes precárias de sobrevivência. O termo "vagabundo", responsável pela prisão e maus tratos de milhares de indivíduos no período pós-abolicionista, esteve presente em leis e códigos penais, no pensamento de legisladores e em textos ditos científicos. O encontro entre lideranças políticas, adversárias do governo Vargas, e a dita vadiagem nas prisôes da Ilha Grande evidenciou tratamentos diferenciados e a naturalização do conceito. Entrevistas com guardas penitenciários da Colônia Agrícola do Distrito Federal, construída em 1942, permitem indicar como essas classificaçóes foram operacionais no interior do sistema prisional e como elas se desdobraram.

Palavras-chave: Ilha Grande; sistema penitenciário; Colônia Correcional de Dois Rios; Colônia Agrícola do Distrito Federal; cultura punitiva.

\section{ABSTRACT}

Based on the study of Ilha Grande's prisons in the first half of the twentieth century, this paper investigates the construction of a punitive culture that criminalized social groups in poor living conditions. The term "vagabundo" [vagrant], which justified the arrest and mistreatment of thousands of individuals in the post-abolitionist period, was present in laws and penal codes, in legislators' thought, and in so-called scientific texts. The meeting between political leaders opposed to Vargas' government and the so-called vagrants indicated differential treatments and the naturalization of the concept. Interviews with prison guards of the Colônia Agrícola do Distrito Federal, built in 1942, indicate how these classifications were operating within the prison system, and how they were deployed.

Keywords: Ilha Grande; prison system; Colônia Correcional de Dois Rios; Colônia Agrícola do Distrito Federal; punitive culture.

* Professora na Universidade do Estado do Rio de Janeiro. Rio de Janeiro-RJ, Brasil. E-mail: myrian@uerj.br. 


\section{RESUMEN}

Con base en un estudio sobre las prisiones de Ilha Grande en la primera mitad del siglo XX, este artículo investiga la construcción de una cultura punitiva que ha criminalizado grupos sociales en condiciones precarias de sobrevivencia. La palabra "vagabundo" [vago], que ha justificado la prisión y el maltrato de miles de individuos en el periodo pos-abolicionista, estuvo presente en leyes y códigos penales, en el pensamiento de legisladores y en textos dichos científicos. El encuentro de liderazgos políticos, adversarias del gobierno Vargas, y la llamada vagancia en las prisiones de la Ilha Grande, evidencia tratamientos diferenciados y la naturalización del concepto. Entrevistas con guardias penitenciarios de la Colonia Agrícola del Distrito Federal, construida en 1942, permiten indicar cómo tales clasificaciones eran operacionales en el interior del sistema penitenciario y cómo se han desdoblado.

Palabras clave: Ilha Grande; sistema penitenciario; Colônia Correcional de Dois Rios; Colônia Agrícola do Distrito Federal; cultura punitiva.

\section{Introdução}

Muito já foi escrito sobre as prisões no Brasil, com denúncias à ineficácia do sistema, à formação de quadrilhas e à barbárie com que são tratados os internos, submetidos à violência de toda sorte, como falta de condições mínimas de higiene, superlotação e tortura física. ${ }^{1}$ Há um consenso entre aqueles que estudam o sistema penitenciário brasileiro de que há uma enorme distância entre, por um lado, leis, normas e regras estabelecidas e, por outro lado, as práticas existentes. ${ }^{2}$ Os diagnósticos e as soluçôes são diversos e acreditamos que eles não sejam excludentes. Entre as causas, podemos destacar: o abismo social que separa ricos de pobres, o caráter seletivo e a morosidade do sistema jurídico, o crescimento de centros urbanos de forma descontrolada e a incapacidade, seja do Estado, seja do sistema econômico, de incluir aqueles que se situam às margens do sistema. $\mathrm{O}$ aumento de verbas públicas, o apoio a jovens carentes, a descriminalização de drogas ilícitas, a capacitação do Judiciário, a desmilitarização da polícia e penas alternativas estão entre algumas das medidas apontadas.

Esse artigo investiga aconstruçáo de uma cultura punitiva voltada para os grupos sociais

\footnotetext{
${ }^{1}$ Este artigo foi escrito ao longo do curso de pós-doutoramento na FFLCH/USP, realizado em 2015, sob orientação do Prof. Dr. Marcos Cesar Alvarez.

${ }^{2} \mathrm{O}$ sociólogo Edmundo Campos Coelho, em livro que é referência ao tema, fez a denúncia, nos anos 1980, de que os regulamentos e leis penais eram peças de retóricas e que não eram operacionalizadas (COELHO, Edmundo Campos. A oficina do diabo. Crise e conflito no sistema penitenciário do Rio de Janeiro. Rio de Janeiro: Iuperj, 1987).
} 
que se encontram em condiçôes precárias de sobrevivência, aspecto que não é tão ressaltado entre as causas do mau funcionamento das prisôes. Para melhor compreensáo do que seja esta cultura punitiva, o trabalho de Michel Foucault se destaca. Sem dúvida, Vigiar e punir, o seu consagrado estudo sobre as prisóes, é importante, mas não responde a todas as nossas questóes. ${ }^{3}$ Foucault, ao se voltar para as transformaçóes que ocorreram nas formas de punição europeias, a partir do final do século XVIII, mostrou a substituição do suplício, em cena pública, por novas formas de vigilância, que ocorreriam em uma nova arquitetura prisional. Embora não possamos generalizar esta observação de Foucault, percebemos ao longo do tempo a formação de uma sociedade disciplinar, também no Brasil, com a criação de instituiçôes cada vez mais especializadas para o controle de jovens, mulheres, não trabalhadores e indivíduos com sofrimento mental. Além disso, é bastante atual sua crítica não apenas à criminologia, mas ao estabelecimento de saberes especializados, que passam a decretar, como verdades absolutas, a natureza daqueles que cometeram os crimes e práticas desviantes. No caso das prisões, as classificações deixam de recair os diversos tipos de crime e passam a incidir sobre os "criminosos". Paralelamente ao arcabouço disciplinar que se forma, encontramos práticas e formas de resistência no interior do sistema prisional que são ambivalentes, complexas e desafiadoras.

Apesar da ênfase dada ao regime disciplinar, Foucault não excluiu a possibilidade de analisarmos a prisão como arena de contestaçôes. Como para ele era essencial romper com o isolamento imposto ao indivíduo encarcerado, bem como com as classificaçóes que lhe eram impostas, ele procurou dar voz àqueles que estavam presos, mostrando que não havia apenas um discurso sobre a prisão e sobre o prisioneiro. Entre 1971 e 1974, coordenou o Grupo de Informaçóes sobre as Prisóes (GIP), um grupo interdisciplinar que reuniu profissionais de diversos campos do saber, bem como personalidades da época como Jean Paul Sartre e Gilles Deleuze, e que teve entre seus objetivos a eliminação da separação existente entre o interior e o exterior da prisão. A fala do preso, como a do louco ou a de qualquer indivíduo marcado pela classificaçáo e pela exclusão, permite que estigmas constituídos sejam quebrados.

Expressóes como "bandido bom é bandido morto" e "cadeia é lugar de preto, pobre e prostituta" são bem conhecidas no Brasil. Como em outros países da América Latina, em que desigualdade social, racismo e extrema pobreza são marcantes, a construção do criminoso consolida-se por práticas que se caracterizam pela desqualificação de uma parcela da população. ${ }^{5}$ A escravidão e as teorias racistas tiveram um importante papel na manutenção

\footnotetext{
${ }^{3}$ FOUCAULT, Michel. Vigiar e punir: nascimento da prisão. Petrópolis: Vozes, 1987.

${ }^{4}$ Ver, entre outros, FOUCAULT, Michel. A ordem do discurso. São Paulo: Ediçôes Loyola, 1996.

${ }^{5}$ Aguirre e Salvatore, por exemplo, enfatizam que a sobreposição entre aspectos dos períodos colonial e pós-independência, na América Latina, abriu novas possibilidades interpretativas sobre leis, crime e punição. AGUIRRE, Carlos; SALVATORE, Ricardo D. Writing the History of Law, Crime, and Punishment in Latin America. In: SALVATORE, Ricardo D.; AGUIRRE, Carlos; JOSEPH, Gilbert M. (Eds.).Crime and Punishment in Latin America.Durham, Londres: Duke University Press, 2001, p. 1-32.
} 
dos africanos e seus descendentes na base da pirâmide social. Em outras palavras, precisamos pensar as prisóes como parte de contextos mais amplos que envolvem aspectos políticos, econômicos, sociais e culturais.

O ponto de partida desse estudo será o uso do conceito "vagabundo" por um antigo guarda penitenciário, que chegou à Ilha Grande no início da década de 1950, período em que o governo Vargas implantava colônias agrícolas para a recuperação de criminosos de bom comportamento. Em seguida, mostraremos a presença da classificação de "vagabundo" tanto em leis e códigos penais como na antropologia criminal. Em terceiro lugar, analisaremos os relatos deixados por militantes políticos sobre a população carcerária das prisóes da Ilha Grande. Por último, voltaremos às declaraçôes do guarda penitenciário para compreender os desdobramentos da categoria de "vagabundo".

\section{Inácio $^{6}$}

Após a desativação do Instituto Penal Cândido Mendes, na Ilha Grande, em 1994, diversos guardas penitenciários e policiais militares continuaram a morar na Vila Dois Rios com suas famílias. $\mathrm{O}$ agente penitenciário Inácio é o funcionário mais antigo a residir no local; ele começou a trabalhar na antiga Colônia Agrícola do Distrito Federal (CADF), em 1951, durante o segundo governo de Getúlio Vargas, quando tinha apenas 26 anos. Morou muitos anos na Vila de Dois Rios. Lá se casou, por duas vezes, e criou seus cinco filhos. Depois de aposentado, continuou a viver na vila. Atualmente passa um tempo na ilha e outro em Angra dos Reis, onde recebe os cuidados da filha. $\mathrm{O}$ antigo funcionário da Colônia Agrícola fez carreira no sistema penitenciário, foi secretário do diretor, chefe de segurança, inspetor, chegando ao cargo de subdiretor do presídio. Como funcionário, teve a oportunidade de terminar seu curso ginasial e fazer alguns cursos, dentre eles um de criminologia e outro de atendimento ao público. Foi contratado como guarda e chegou ao cargo de inspetor penitenciário federal. Ele tem um enorme orgulho de sua trajetória e gosta de contar casos que atraem a atenção dos visitantes. Nestor Veríssimo, Tancredo Neves, Getúlio Vargas, Capitão Murilo Maldonado, Capitão Inair, mas também Lúcio Flávio, Escadinha, Chiquito, Rogério Lengruber, Comando Vermelho e Terceiro Comando, ou seja, nomes de autoridades, de infratores e de "organizaçóes criminosas" que ocuparam as primeiras páginas de jornais são sempre citados para ilustrar acontecimentos de sua história de vida. ${ }^{7}$

Desde menino, sua vida girou em torno de presídios. O pai foi almoxarife, chegando a

\footnotetext{
${ }^{6}$ Não serão utilizados nomes verdadeiros para proteção daqueles que nos ofereceram seus depoimentos. As entrevistas aqui citadas fazem parte da pesquisa Memória e violência nas prisóes da Ilha Grande, que, em seus desdobramentos, obteve apoio do CNPq, Uerj e FFLCH/USP.

${ }^{7}$ A manutenção da identidade do entrevistado foi mantida náo só porque os relatos e o período estudado o identificam, mas por autorizaçáo expressa do depoente. Esta e outras entrevistas fazem parte do acervo da pesquisa História e Memória das Prisóes da Ilha Grande/ICS/Uerj.
} 
assumir o cargo de subdiretor da Penitenciária Especial de Fernando de Noronha. Seu pai era pernambucano e sua mãe, amazonense. Os funcionários moravam na ilha com os parentes, e Inácio e oito irmãos lá viveram, com os pais, por algum tempo. Da infância na ilha Fernando de Noronha, as lembranças são muitas. Fortaleza no topo da montanha construída pelos holandeses, Igreja Nossa Senhora dos Remédios, praia do Cachorro, praia de Santo Antônio, barcos pesqueiros, lagostas e muito peixe, tudo isso fez parte de sua vida de menino. Lembra-se também de ter viajado em navios alemães e dos presos que eram levados para a ilha.

Tentaram fazer uma revolução em Noronha uma vez... tivemos que subir... eu me lembro de meu pai, armado de fuzil, de revólver. Subiu. Lá era uma fortaleza do tempo dos holandeses, que tem no alto, construída. Eles estavam atirando neles todos. Eu já tinha uns dez anos. A mamãe com cuidado, porque a gente queria correr para ver, a mamãe... nove filhos correndo... botando pra dentro de casa. A polícia correndo dando tiro. Em Noronha eu me lembro disso. ${ }^{8}$

Quando o pai foi transferido para Recife, Inácio iniciou seu curso ginasial e, ao completar 18 anos, cumpriu o serviço militar, na Aeronáutica, por dois anos. Trabalhou em algumas empresas, uma delas americana, até que, a partir de um concurso promovido pelo Estado do Alagoas, em que tirou segundo lugar, conseguiu um emprego de topógrafo. Ficou neste cargo por três anos. Voltou para Recife, onde trabalhou em algumas empresas. Mas, entâo, acontecimentos fizeram com que ele fosse para Dois Rios:

Trabalhava em uma firma em Recife e aconteceu um problema por causa de festa, de namorada... Aí eu fiz uma arte lá... e aí embarquei à meia-noite, a bordo do Itaquera, em 1951. Embarquei à meia-noite e vim bater na Ilha Grande, onde estava minha irmã. (...) Aí passei a ser agente penitenciário. ${ }^{9}$

Inácio não nos dá muitos detalhes do que aconteceu em Recife, mas explica que a "arte" cometida foi séria o bastante para que ele viajasse para a Ilha Grande no mesmo dia. Essa "arte" não foi considerada um crime nem pelo entrevistado, nem por seus familiares, nem pelos órgãos oficiais, o que já nos indica a presença de uma complexa rede de significados relacionada com o crime e as puniçóes. Como uma das irmãs de Inácio havia se casado com um funcionário do sistema penitenciário, que fora transferido de Fernando de Noronha para Dois Rios, Inácio lá encontrou abrigo. Logo após sua chegada, foi nomeado guarda da Colônia Agrícola do Distrito Federal, pelo ministro da Justiça, Negrão de Lima.

Quando perguntamos a Inácio se os presos de Fernando de Noronha tinham vindo para

\footnotetext{
${ }^{8}$ Trecho da entrevista realizada em outubro de 2010. Acervo do projeto de pesquisa Memória e violência na Ilha Grande, que, em seus desdobramentos, obteve apoio do CNPq, Uerj e FFLCH/USP.

${ }^{9}$ Ibidem.
} 
a Ilha Grande, ele nos disse que os presos de lá não vieram, somente os guardas, e nos ofereceu como explicação a diferença da população prisional de cada um dos estabelecimentos citados.

Em Fernando de Noronha, o preso, quando estive lá, [usava] era aquela roupa de zebra, listrada, de zebra, o preso... Aqueles cangaceiros de Lampião... como Mata Velha, Sangue Azul, Abel, eu me lembro desses... eu lembro que eram presos valentes, eram os presos condenados a mais de trinta anos de cadeia... iam para Noronha. Caneca Amassada, apelido de preso, né? ... Aqui... vamos dizer assim... não era uma penitenciária, era um presídio. Para cá vinham os presos que tinham poucos anos de cadeia. ${ }^{10}$

Os presos políticos que estavam em Fernando de Noronha foram transferidos para Dois Rios, mas os demais presos foram transferidos para as penitenciárias de Recife. Inácio se referia a estes presos. Para ele, os cangaceiros de Lampião eram "valentes", enquanto aqueles que eram enviados para as prisóes da Ilha Grande eram os "vagabundos". O guarda penitenciário fez parte de uma família de funcionários de estabelecimentos penais; seu discurso era compartilhado entre pares. Além disso, algumas das definiçôes e categorias utilizadas no interior das instituiçôes carcerárias também fizeram como fazem até hoje parte do vocabulário das leis penais brasileiras e do pensamento jurídico nacional.

\section{A presença dos "vagabundos" no texto da lei}

As Ordenaçóes e Leis do Reino de Portugal, compiladas no Código Filipino, foram bastante influentes no Brasil, não só no período colonial, quando organizava todo o sistema jurídico, como em períodos posteriores. As penas eram severas e variadas; incluíam desde a perda e confisco de bens a açoites, mutilação física, marcação com ferro em brasa e morte, por esquartejamento e pela forca. Todos aqueles que tinham privilégios, ou seja, fidalgos, cavaleiros e doutores, não poderiam ser submetidos às penas mais duras. Aqueles que eram desprivilegiados não tinham qualquer direito frente o juiz, sendo a tortura utilizada como meio de obtenção de confissóes. Segundo o historiador Thomas Holloway, entre 1810 e $1821,80 \%$ de todos aqueles que recebiam uma sentença por crimes cometidos eram de indivíduos escravizados. Outros 19\% do total eram ex-escravos e somente cerca de $1 \%$ era de indivíduos livres que nunca tinham sido escravos. Holloway cita o comentário do comerciante inglês Luccock, segundo o qual os brancos aos poucos se haviam convencido de que estavam acima das leis. As leis, portanto, eram bastante seletivas. ${ }^{11}$

\footnotetext{
${ }^{10}$ Ibidem.

${ }^{11}$ HOLLOWAY, Thomas H. Policing Rio de Janeiro. Repression and resistance in a $19^{\text {th }}$ century city. Albu-
} 
No império, o Código Criminal de 1830 substituiu o Livro V das Ordenaçôes e apresentou a influência de ideologias liberais, correntes na Europa. As penas de suplício, por exemplo, foram substituídas pela pena de privação da liberdade. Contudo, manteve-se no Código a manutenção dos açoites para a punição de escravos. Assim sendo, diferentemente da Europa, onde as penas deixaram de ser imputadas sobre o corpo e passaram a ser direcionadas ao comportamento através de métodos disciplinares, ${ }^{12}$ no Brasil do século XIX, os suplícios ainda eram vistos como uma boa estratégia para manter a ordem. Dizia o Código:

Se o réu for escravo, e incorrer em pena, que não seja a capital, ou de galés, será condenado na de açoites, e depois de os sofrer, será entregue a seu senhor, que se obrigará a trazê-lo com um ferro, pelo tempo, e maneira que o Juiz designar. O número de açoites será fixado na sentença; e o escravo não poderá levar por dia mais de cinquenta. ${ }^{13}$

O Código de 1830 justificava o crime se este fosse cometido pelos senhores a seus escravos:

Será o crime justificável, e não terá lugar a punição dele, [\$6], quando o mal consistir no castigo moderado, que os pais derem a seus filhos, os senhores a seus escravos, e os mestres a seus discípulos; ou desse castigo resultar, uma vez que a qualidade dele, não seja contrária às leis em vigor. ${ }^{14}$

Ainda, segundo Holloway, coube às instituiçôes policiais estabelecidas no Rio de Janeiro a apreensão e punição de escravos fugitivos, tarefas estas que eram realizadas anteriormente pelos capitães do mato. ${ }^{15}$ No patrulhamento das ruas, os castigos corporais, embora sem base legal, eram utilizados, pois a intenção era a de intimidar "escravos" e "vadios" para mantê-los submissos. ${ }^{16}$ A lei legitimava a violência, através de puniçôes desmedidas e cruéis, instaurando o medo entre a população escrava. Não se tratava, portanto, de construir um corpo autodisciplinado através da pena, mas, sim, de manter aqueles que eram escravizados sob o jugo dos chicotes.

Apesar da dificuldade em contabilizar o percentual da população penal constituída por africanos e seus descendentes, Holloway não hesita em concluir que o sistema policial nascido da crise de 1831 firmou-se com o intuito de vigiar e reprimir indivíduos escravizados e pobres livres. No final de 1841, os agentes de polícia adquiriram autoridade para inves-

querque: University of New Mexico, p. 51-2, 1993.

${ }^{12}$ FOUCAULT, Michel. Vigiar e punir: nascimento da prisão, op. cit.

${ }^{13}$ Código Criminal de 1830, Parte Primeira, "Dos Crimes, e das Penas", Título II, "Das Penas", Capítulo I,

"Da qualidade das penas, e da maneira como se hão de impor, e cumprir", artigo 60.

${ }^{14}$ Código Criminal de 1830, Parte Primeira, “Dos Crimes, e das Penas”, Título I, “Dos Crimes”, Capítulo II,

“Dos Crimes Justificáveis", artigo 14, $\$$ 6․

${ }^{15}$ HOLLOWAY, Thomas H. Policing Rio de Janeiro. Repression and resistance in a $19^{\text {th }}$ century city, op. cit., p. 63.

${ }^{16}$ Ibidem. p. 51. 
tigar, prender, julgar e sentenciar os pequenos infratores, sem a intervenção de advogados, promotores ou autoridades judiciais superiores. ${ }^{17}$ É interessante, portanto, observarmos a constituição desses "pobres livres”. O Código de 1830 denominava os culpados de crimes menores de "vadios". Entre esses crimes estavam as ofensas da religião, aquelas da moral e bons costumes, a formação de sociedades secretas, os ajuntamentos ilícitos, o uso e fabrico de armas proibidas, o uso de nomes e títulos indevidos, o uso indevido da imprensa, mendicância e a vadiagem. As penas variavam de multas a pequenos períodos de prisão (oito a 24 dias). A imposição da pena recaía sobre os que não tinham ocupação honesta e nem renda suficiente. ${ }^{18}$

No Código Penal de 1890, promulgado um ano após a Proclamação da República, e dois anos após a assinatura da Lei Áurea, ofensas menores, como alcoolismo e vadiagem, deixaram de ser classificadas como "crimes" e passaram a ser "contravençôes", ou seja, atitudes indesejáveis às autoridades. ${ }^{19}$ Contudo, as contravenções passaram a ser descritas com mais detalhes, envolvendo novos tipos, entre eles os "ébrios" e os "capoeiras", e obtendo penas maiores. Se antes a pena máxima para os infratores era de um mês, agora ela chegava a três anos, pena esta a ser cumprida em colônias penais estabelecidas em ilhas marítimas, nas fronteiras do território nacional ou em presídios militares. Interessante também observar que o termo "vadio" aparece agora na lei como sinônimo de "vagabundo".

Art. 399. (...) $\$ 1$ o Pela mesma sentença que condenar o infrator como vadio, ou vagabundo, será ele obrigado a assinar termo de tomar ocupação dentro de 15 dias, contados do cumprimento da pena. (...)

Art. 400. Se o termo for quebrado, o que importará reincidência, o infrator será recolhido, por um a três anos, a colônias penais que se fundarem em ilhas marítimas, ou nas fronteiras do território nacional, podendo para esse fim ser aproveitados os presídios militares existentes. (...) Art. 401. A pena imposta aos infratores, a que se referem os artigos precedentes, ficará extinta, se o condenado provar superveniente aquisição de renda bastante para sua subsistência; e suspensa, se apresentar fiador idôneo que por ele se obrigue (...). ${ }^{20}$

Continuava a ser punido, agora descrito como "vadio" ou "vagabundo", aquele que deixava de exercitar profissão e não tinha meios de subsistência. $\mathrm{O}$ tratamento desigual destinado aos mais pobres se tornava mais uma vez evidente, pois a lei estabelecia a extinção da

\footnotetext{
${ }^{17}$ Ibidem. p. 156.

${ }^{18}$ Código Criminal de 1830, Parte Quarta, “Dos crimes policiaes”, Capítulo IV, "Vadios e Mendigos”, artigos 296 e 295 .

${ }_{19}^{19}$ Código Penal de 1890, Livro I, “Dos crimes e das penas”, Título II, “Dos crimes e dos criminosos”, artigos $7^{\circ}$ e e $8^{\circ}$.

${ }^{20}$ Ver Código Penal de 1890, Livro III, "Das contravençôes em espécie”, Capítulo XII, "Dos mendigos e ébrios", e XIII, "Dos vadios e capoeiras", artigos 391 a 404.
} 
pena se o condenado provasse ter renda para sua subsistência ou fiador idôneo. A situação financeira do acusado e sua inserção no mundo do trabalho continuaram a desempenhar um papel fundamental na aplicação da pena.

Certamente o recrudescimento da repressão aos contraventores foi uma resposta das autoridades às ameaças que surgiam após a abolição do sistema escravista. A nova legislação permitia o controle de uma grande parcela da população que se encontrava sem recursos e sem empregos, ocupando as camadas mais baixas da estratificação social. ${ }^{21}$ Quando procuramos dados estatísticos para saber a quem a polícia reprimia de fato, vemos que a situaçáo descrita por Holloway, entre 1810 e 1821, perpetuava-se. Segundo o historiador, 60\% dos delitos daquele período poderiam ser considerados como ofensas menores à ordem pública, sendo $25 \%$ relacionados a pequenos furtos e somente $12 \%$ à agressão física ou ferimento causado a outrem. ${ }^{22}$ Passados cem anos, observamos que os sentenciados por crimes contra pessoa e patrimônio representavam apenas $8,4 \%$ dos encarceramentos, sendo os $91,6 \%$ restantes relativos a contraventores ("doentes mentais" e "ébrios", 50,8\%; "menores abandonados", 29,6\%; "vadios", 8,5\%; e "mendigos", 2,7\%). ${ }^{23}$ Mesmo considerando as dificuldades de obtenção de dados estatísticos precisos, podemos dizer que o sistema prisional continuava voltado para aqueles setores da populaçáo que não tinham recursos e estavam à margem do mercado de trabalho.

Em 1930, Getúlio Vargas, ao chegar ao poder, fechou o Congresso Nacional, suspendeu a Constituição, e reforçou as instituiçôes ligadas à segurança pública. As forças policiais foram reestruturadas para responderem a novos pactos sociais constituídos e para reprimir os grupos políticos que se colocavam contra o governo. Após 1937, com o estabelecimento do Estado Novo, houve uma intervenção gigantesca na esfera jurídico-penal e nos estabelecimentos penitenciários. No início da década de 1940, duas leis foram criadas, o Código Penal e a Lei das Contravençôes Penais, ambas vigentes até os dias atuais, apesar das diversas modificaçôes sofridas. O Código Penal regulou a pena daqueles que cometiam infraçóes consideradas mais graves, como homicídio e roubo, com lesões a terceiros, e a punição indicada era a reclusão. A Lei das Contravenções Penais punia os delitos menos graves, como vadiagem, com multa ou prisão simples. Esta última deveria ser cumprida sem rigor penitenciário, em estabelecimento especial, ou em seçáo especial de prisáo comum, em regime semiaberto

\footnotetext{
${ }^{21}$ Sobre a tentativa de controle de pequenos infratores que se moviam entre a legalidade e a ilegalidade nas ruas da cidade, ver, entre outros, CHALHOUB, Sidney. Trabalho, lar e botequim. O cotidiano dos trabalhadores no Rio de Janeiro da Belle Epoque. São Paulo: Brasiliense, 1986; e BRETAS, Marcos Luís. Ordem na cidade: o exercício cotidiano da autoridade policial no Rio de Janeiro, 1907-1930. Rio de Janeiro: Rocco, 1997.

${ }^{22}$ HOLLOWAY, Thomas H. Policing Rio de Janeiro. Repression and resistance in a $19^{\text {th }}$ century city, op. cit., p. 53.

${ }^{23}$ Ver relatório do ministro de Justiça, Dr. Rivadávia da Cunha Corrêa, ao presidente da República, relativo aos anos 1912 e 1913. Disponível em: <http://brazil.crl.edu/bsd/bsd/u1909/000001.html>. Acesso em: 20 jul. 2016.
} 
ou aberto. A pena privativa de liberdade foi comum aos dois tipos de infratores, sendo que o tempo em que o condenado passava na cadeia variava de alguns poucos meses até cinco anos, em casos de contravenção, e até 30 anos, em crimes como homicídio qualificado.

No que diz respeito aos denominados "vadios" ou "vagabundos", as instituiçôes jurídico-penais e as forças policiais continuaram com sua tarefa de repressão. A definição de "vadiagem", presente no artigo número 59 da Lei das Contravençôes Penais, é válida até os dias atuais, e não sofreu grandes modificaçôes, pois pelo texto da lei "vadio" continua a ser definido como sendo alguém passível de ser preso por se entregar à ociosidade e por não ter renda que lhe assegure meios de subsistência. Aqueles que não trabalham, mas têm renda, não são considerados "vadios". ${ }^{24}$

\section{A contribuição da antropologia criminal}

Alguns estudos têm enfatizado a importância adquirida pela antropologia criminal nas faculdades brasileiras de medicina e de direito, no início do século XX, ainda que em franca decadência no continente europeu. ${ }^{25}$ As teorias de Cesare Lombroso, médico e criminalista italiano, deram origem à Escola Positiva, que postulava a tese do criminoso nato. Lombroso dedicou-se a estudos antropométricos de criminosos e os associou à humanidade primitiva e aos animais inferiores. Em sua obra mais conhecida, O homem delinquente, publicada em 1876, afirmou que a assimetria da face e do crânio, orelhas grandes em demasia, arcos do supercílio proeminentes, mandíbulas exageradas e braços excessivamente compridos eram sinais de uma personalidade criminosa. ${ }^{26}$ Essa tese teve alguns seguidores na Itália, na Europa pré-nazista e na América Latina.

Parte significativa da intelectualidade brasileira, preocupada com a grande proporção de cidadãos negros no período pós-abolicionista, utilizou os escritos de Lombroso para associar características raciais, mais precisamente traços fenotípicos dos descendentes dos africanos, ao comportamento criminoso. O médico legista Raymundo Nina Rodrigues (1852-1906), professor da Faculdade de Medicina da Bahia, foi um dos mais importantes seguidores de Lombroso no Brasil, defendendo não só a relação entre raça e responsabilidade penal, como

\footnotetext{
${ }^{24}$ Decreto-Lei no 3.688 , de 3 de outubro de 1941.

${ }^{25}$ Ver, entre outros, FRY, Peter; CARRARA, Sérgio Luis. As vicissitudes do liberalismo no direito penal brasileiro. Revista Brasileira de Ciências Sociais, v. 1, n. 2, p. 48-54, 1986; ALVAREZ, Marcos César. Bacharéis, criminologistas e juristas: saber jurídico e a nova escola penal no Brasil (1889-1930). São Paulo: USP/FFLCH, 1996; ALVAREZ, Marcos César. A criminologia no Brasil ou como tratar desigualmente os desiguais. Dados Revista de Ciências Sociais, v. 45, n. 4, p. 677-704, 2002; SALLA, Fernando. As prisóes em São Paulo: 18221940. São Paulo: Annablume, 1999; e QUEIROZ, Rafael Mafei Rabelo. A modernização do direito penal brasileiro: sursis, livramento condicional e outras reformas do sistema de penas clássico no Brasil, 1924-1940. São Paulo: Quartier Latin do Brasil, 2007.

${ }^{26}$ LOMBROSO, Cesare. O homem delinquente. Porto Alegre: Ricardo Lenz, 2001.
} 
a ideia mais geral de que cabia aos indivíduos da raça ariana náo permitir que negros e mestiços interferissem nos destinos do país. ${ }^{27}$ Suas teses eram consideradas como parte da ciência avançada da época e tiveram muitos seguidores. ${ }^{28}$

As teorias raciais, a antropologia criminal e as diversas classificaçôes e tipologias de doenças e crimes fizeram parte dos mecanismos de controle da sociedade brasileira de fins do século XIX e início do XX. Nas primeiras décadas do período republicano, observa-se a consolidação da loucura como doença mental pelo saber médico e a criação dos hospícios; ${ }^{29}$ uma nova percepçáo da infância e a promulgação do primeiro Código de Menores; ${ }^{30}$ bem como a criaçáo de diversas categorias de contraventores e a abertura de asilos, manicômios e colônias correcionais. ${ }^{31}$

A obra de Lombroso, ao ser incorporada pelos estudos criminalistas da época, implicou em propostas como a individualização da pena, ou seja, a definição do castigo a partir das características próprias do réu e não em função do delito e de critérios universais, como no direito clássico. Autoridades como Cândido Mendes, Lemos Britto e Heitor Carrilho, que ocuparam cargos decisórios no governo desde a década de 1920, acreditaram ser possível identificar tipos e taras psicobiológicas e indicar os tratamentos adequados para corrigi-los. Cândido Mendes esteve à frente do Conselho Penitenciário, criado em 1924, e da Inspetoria Geral Penitenciária, de 1934. Lemos Britto foi presidente desta última instituição de 1939 até 1957. Heitor Carrilho foi inicialmente chefe da Seção Lombroso do Hospício Nacional de Alienados, e, entre 1921 e 1954, data de sua morte, diretor do Manicômio Judiciário do Rio de Janeiro. Durante o Estado Novo, influíram fortemente tanto na construção do Código Penal de 1940 como na Lei das Contravençôes Penais, de 1941. Ao mesmo tempo que a elite jurídica brasileira possibilitava maior repressão aos contraventores, cujas penas aumentaram para até cinco anos de prisão, ela também criava instrumentos como sursis e livramento condicional, que eram aplicados aos "crimes acidentais" cometidos por homens bons. ${ }^{32}$

Os postulados sobre a natureza diferenciada dos homens legitimaram um conjunto de estereótipos e práticas, tanto nas ruas como nas prisóes. No caso da prisão dos contraventores, eram os policiais que, desde o tempo do império, classificavam o delito cometido e

\footnotetext{
${ }^{27}$ RODRIGUES, Nina. As raças humanas e a responsabilidade penal no Brasil. São Paulo: Companhia Editora Nacional, 1938.

${ }^{28}$ Sobre a importância de Nina Rodrigues na consolidação da antropologia criminal no Brasil, ver CORRÊA, Mariza. As ilusões da liberdade: a escola Nina Rodrigues e a antropologia no Brasil. Bragança Paulista: Edusf, 1998.

${ }^{29}$ ENGEL, Magali Gouveia. Os delírios da razão: médicos, loucos e hospícios (Rio de Janeiro, 1830-1930). Rio de Janeiro: Editora Fiocruz, 2001.

${ }^{30}$ VIANNA, Adriana de Resende Barreto. O mal que se advinha: polícia e menoridade no Rio de Janeiro, 1910-1920. Rio de Janeiro: Arquivo Nacional, 1999.

${ }^{31}$ SANTOS, Myrian Sepúlveda. Os poróes da república: a barbárie nas prisóes da Ilha Grande (1894-1945). Rio de Janeiro: Eduerj/Garamond, 2009.

${ }^{32}$ QUEIROZ, Rafael Mafei Rabelo. A modernização do direito penal brasileiro: sursis, livramento condicional e outras reformas do sistema de penas clássico no Brasil, 1924-1940, op. cit., p. 244-263.
} 
decidiam para que instituições os "mendigos", os "vadios", os "bêbados", as "prostitutas" e os "capoeiras" deveriam ser encaminhados. Foram criados laboratórios de antropologia criminal e gabinetes de identificação no aparato policial com o objetivo de isolar e classificar indivíduos indesejados e perigosos e proteger a vida coletiva. A polícia republicana identificava contraventores e criminosos a partir de suas características anatômicas.

A Colônia Correcional de Dois Rios (CCDR), estabelecida na Ilha Grande, foi criada, em 1894, para receber "ébrios", "mendigos", "prostitutas", "capoeiras” e "vadios", entre outros. ${ }^{33}$ Os chamados "vagabundos" reincidentes caíam no esquecimento, cumprindo penas bem maiores que as estipuladas, sem qualquer acesso à Justiça. Os relatos que foram deixados da antiga CCDR traçam uma dinâmica de maus-tratos e extermínio de indivíduos que perambulavam pelas ruas, responsáveis ou não por pequenas infraçóes. $\mathrm{Na}$ prisão, eram submetidos à fome, ao frio, às doenças epidêmicas e às sevícias de todo tipo. Se morriam, eram jogados em covas rasas em um cemitério improvisado que lá havia.

\section{Os "vagabundos" nas memórias de presos políticos}

O governo de Getúlio Vargas, de 1930 a 1945, manteve-se através de uma forte repressão política. ${ }^{34} \mathrm{~A}$ polícia especial que foi organizada era responsável pela tortura e pelo envio de prisioneiros para prisôes. A Colônia Correcional de Dois Rios tornou-se o local de isolamento de diversos militantes do Partido Comunista. Até então, pouco se sabia sobre o que acontecia na Colônia, a qual, muito esporadicamente, tornava-se o objeto de jornalistas curiosos.

Em 1934, uma série de reportagens de Walter Prestes foi publicada no jornal O Globo, mostrando um cenário dantesco. ${ }^{35}$ As reportagens foram extensas e denunciaram um cotidiano de trabalhos forçados e de maus-tratos próximo ao da antiga escravidáo. Homens eram obrigados a transportar vigas pesadíssimas, muito acima de suas forças, na subida e descida dos morros. Mas o motivo da ida do jornalista à Ilha Grande foi o espancamento público de cinco presidiários, punição esta que desencadeou a abertura de inquérito contra o diretor do presídio, Marcílio Souto Maior. O castigo ocorrera ao som de uma marcha, em presença dos administradores da prisão, de centenas de correcionais, e das famílias dos funcionários. A cena foi descrita com detalhes:

Cada algoz estava munido de um "camarão". "Camarão" é um cipó que, depois de levado ao fogo, se torna extremamente flexível e adquire uma cor avermelhada. Os presidiários tinham

\footnotetext{
${ }^{33}$ Decreto-Lei no 1.794 , de 11 de setembro de1894.

${ }^{34}$ Sobre as prisóes no governo Vargas, ver CANCELLI, Elizabeth. $O$ mundo da violência - a polícia da era Vargas. Brasília: Editora UnB, 1994, e PEDROSO, Regina Célia. Os signos da opressão. História e violência nas prisóes do Brasil. São Paulo: Arquivo do Estado/Imprensa Oficial do Estado, 2003.

${ }^{35}$ A Ilha da Maldição, jornal $O$ Globo, 4 abr. 1934, p. 1-2.
} 
o tronco despido. Os guardas, empunhando o "camarão", experimentavam-lhe a flexibilidade, dobrando-o até se tocarem os extremos. Um grupo de funcionários e guardas, entre os quais se achavam o Dr. Souto Maior e o almoxarife Amorim, aguardava a realização do espetáculo. Nas janelas gradeadas dos alojamentos, centenas de cabeças se amontoavam. Um vozerio surdo roncava, vindo dos dormitórios, como o reboar dos trovóes longínquos. Junto à fileira dos que iam ser supliciados, o cãozinho "Vigilante", de propriedade de Valentim Teixeira Leite, moviase nervosamente, pulando nas pernas do seu dono. Não muito longe, de frente para os cinco condenados, estava formada a banda de música. ${ }^{36}$

O espancamento teve repercussão e o tenente Victorio Caneppa, gaúcho, nascido em Alegrete, no Rio Grande do Sul, assumiu a direção da Colônia. Os diretores eram, neste período, nomeados diretamente por Getúlio Vargas. Anteriormente, Caneppa fora indicado para dirigir o Lazareto, uma prisão improvisada a partir dos prédios do antigo Lazareto, para receber os revoltosos de 1932. Defendeu a existência de uma prisão própria para os "transviados" para que fosse possível a recuperação destes, e foi autor de um projeto neste sentido. ${ }^{37}$ Em relatório oficial a Filinto Müller, o chefe de Polícia de Getúlio Vargas, criticou a transferência sistemática de condenados por penas diversas para a Colônia, o que tornava mais calamitosas as condições lá encontradas. Descreveu as péssimas condiçóes do estabelecimento e declarou que não tinha os instrumentos necessários para torná-lo um campo de detenção razoável.

São prédios antigos com capacidade para mais de uma centena de detentos, muito mal distribuídos e de higiene dificílima, motivo pelo qual vivemos constantemente sobressaltados pela ideia de uma epidemia. Se aqui se deflagrasse qualquer moléstia de caráter contagioso seria uma calamidade, pois a promiscuidade em que vivem os detentos e a nossa natural falta de recursos nos traria, além dos dissabores de ver sucumbir grande número de detentos, luto para nossas famílias que residem a poucos metros dos pavilhóes. Devo dizer que o alojamento das mulheres é um verdadeiro pardieiro, apresentando aspecto ainda mais chocante que o dos homens. Posso dizer sem medo de contestação que a colônia se propóe à regeneração de transviados, dá a estes mesmos transviados um tratamento de madrasta, que, sem dúvida, longe de os atemorizar, aumenta-lhes o rancor pelos sãos de espírito. ${ }^{38}$

Apesar de ser diretor de uma das piores masmorras do Estado, Caneppa foi crítico do seu funcionamento e fez parte de um grupo de criminologistas responsáveis pela elaboração

\footnotetext{
${ }^{36}$ Ibidem.

${ }^{37}$ Arquivo Nacional. Fundo MJNI. Coleção Justiça. Processo 137. Cx. 846. Projeto de Construção da Colônia Penal Agrícola da Ilha Grande, 16 out. 1936.

${ }^{38}$ Arquivo Nacional. Biblioteca. Código 3789: 1181. Comunicado do diretor da Colônia Victorio Caneppa ao chefe de polícia Filinto Müller.
} 
de leis, normas e regulamentos penais que visavam uma mudança no sistema prisional. Em 1938, ele deixou a Colônia Correcional de Dois Rios e assumiu a direção da Penitenciária Central, com a superintendência de Fernando de Noronha. Foi também diretor do Presídio Feminino, em 1945. A partir de 1947, tornou-se responsável, como proprietário, pela Revista Brasileira de Criminologia. O primeiro número da revista traz um artigo de Enrico Ferri, seguidor de Lombroso, sobre a aliança entre direito e sociologia criminal. Caneppa, como outros intelectuais da época, procurou construir um sistema penitenciário dentro dos parâmetros da antropologia criminal.

Com a chegada dos prisioneiros políticos, o cotidiano da Colônia foi denunciado pela imprensa de forma mais sistemática. Imediatamente após a prisão de militantes políticos, sindicatos, políticos e lideranças partidárias começaram a denunciar a barbárie e o público passou a ter mais informaçôes sobre o que acontecia no local. ${ }^{39}$ O Socorro Vermelho, uma organização ligada à Internacional Comunista, não hesitou em distribuir panfletos comparando a CCDR à Clevelândia do Norte, antigo presídio localizado na cidade de Oiapoque, na regiáo amazônica, para onde centenas de pessoas, entre elas criminosos comuns e dissidentes do governo de Arthur Bernardes, foram levadas, morrendo em sua maioria, se não na travessia, no próprio presídio. Além disso, diversos dos militantes que lá foram encarcerados deixaram suas memórias e nelas o registro da vida prisional na Colônia.

Heitor Ferreira Lima, liderança do Partido Comunista, esteve preso na CCDR, entre 1932 e 1934, e publicou suas memórias em 1982, pela editora Brasiliense, com prefácio de Paulo Sérgio Pinheiro, e selo do Arquivo de História Social Edgard Leuenroth, da Unicamp. $\mathrm{O}$ interesse maior das memórias era o registro e a reflexão sobre a trajetória do $\mathrm{PCB}$, de sua fundação até os anos 1940. Ainda assim, a selvageria dos guardas com relação aos demais presos está presente no relato:

Os castigos com varas de marmelo, aplicados principalmente aos fugitivos recapturados, constituía ato revoltante pela sua selvageria e covardia. Colocavam o recapturado em meio ao pátio, quatro ou cinco guardas golpeando-o rude e incessantemente, com toda força, o diretor do presídio assistindo, impassível, embora o surrado, com o corpo lanhado e dolorido, recorresse a ele, pedindo perdão, ajoelhado, agarrado a suas botas, em desespero incontrolado. ${ }^{40}$

Ainda, segundo Lima, os presos políticos não eram tratados como os presos comuns e recebiam um tratamento diferenciado, usufruindo de maior liberdade. Eles não realizaram serviços domésticos para os guardas e alguns deles obtiveram até mesmo o direito de morar com mulher e filhos na Colônia.

\footnotetext{
${ }^{39}$ Ver, por exemplo, carta do deputado João Café Filho, 1936, para que sejam averiguadas as condições de tratamento dadas aos presos políticos. Arquivo Nacional. Fundo MJNI. Coleção Justiça. Processo 362/36. Cx. 69.

${ }^{40}$ LIMA, Heitor Ferreira. Caminhos percorridos: memórias de militância. São Paulo: Brasiliense, 1982, p. 169.
} 
Em obra póstuma, Uma vida em seis tempos, publicada em 1969, Leôncio Basbaum, também um dos quadros do $\mathrm{PCB}$, fez uma reflexão sobre os seus 40 anos de militância política e de suas diversas prisóes. Entre setembro e dezembro de 1932, ele ficou preso na Colônia Correcional e, tal como Lima, fez alguns comentários sobre as condiçôes da prisão e sobre a população carcerária. Segundo Basbaum, na época de sua prisão, estavam, na CCDR, presos políticos, algumas poucas pessoas que aparentavam melhor posição social e uma maioria de "malandros de todos os tipos", descritos por ele como "vagabundos", "ladróes pés de chinelo", "descuidistas", "mendigos esfarrapados", "falsos cegos", "falsos aleijados", "bêbados" e "doentes mentais". As condiçôes de habitação eram péssimas e a comida, intragável. A maioria dos presos tinha armas improvisadas e era comum que rapazes pivetes buscassem proteção em ladrôes mais velhos. Para o autor, na Ilha Grande encontrava-se a escória da sociedade, presos irrecuperáveis que só conheciam dois mundos, o dos otários e o deles próprios. Não tinham noção de seus direitos ou de dignidade humana e eram abandonados na Colônia, sem condenação, sem estarem sob os cuidados da Justiça. Eles tinham sua existência ignorada. ${ }^{41}$

Os relatos de Lima e Basbaum sobre a permanência na Colônia são bem próximos e neles fica bem claro não só que eles conseguiram manter seus coletivos políticos, com cursos de marxismo e debates organizados, mas também que o tratamento que eles recebiam da direção e dos guardas da Colônia era diferenciado, quando comparado ao tratamento destinado aos demais presos. Através dos guardas, eles conseguiam mandar informaçóes para seus partidos, receber cigarros e jornais e até mesmo cartas de parentes. Segundo Basbaum, o companheiro Nute, junto com a esposa e o filho de três anos, morava em uma casa fora dos limites da prisão. Ele próprio, como era médico, trabalhava no hospital, também fora do presídio, e desfrutava de certas regalias, como passear na praia e tomar banho de sol.

Nos anos 1933 e 1934, período em que a sociedade se preparava para eleger democraticamente uma nova Constituição, fortaleceram-se diversas organizações contrárias ao governo Vargas, polarizadas politicamente por comunistas e integralistas, e medidas foram decretadas para reprimir crimes contra a segurança nacional, ou seja, à ordem política e social. A famosa Delegacia Especial de Segurança Política e Social (DESPS), criada neste período, aumentou o controle sobre movimentos sociais. ${ }^{42}$ A Chefia de Polícia do Distrito Federal, cargo ocupado por Filinto Müller de 1933 a 1942, passou a ter ligaçáo direta com o presidente da República, limitando os poderes do Ministério da Justiça. O chefe de polícia e seus auxiliares passaram a ter atuação direta sobre detençôes, transferências e questốes administrativas.

Em março de 1935, foi lançada a Aliança Nacional Libertadora (ANL), uma ampla frente de esquerda que propunha um governo popular. Em julho, com base na Lei de Se-

\footnotetext{
${ }^{41}$ BASBAUM, Leôncio. Uma vida em seis tempos. São Paulo: Alfa-Omega, 1976.

${ }^{42}$ O Decreto-Lei no 22.332 , de 10 de janeiro de 1933, que é responsável pela reforma do serviço policial do Distrito Federal e pela criação da Delegacia Especial de Segurança Política e Social (DESPS), deu maiores poderes aos delegados, diretamente subordinados ao chefe de polícia.
} 
gurança Nacional (LSN), a organização foi colocada na ilegalidade. Em novembro, após a insurreição comunista ocorrida nas cidades de Natal, Recife e Rio de Janeiro, foi decretado o estado de sítio e, desta vez, não mais lideranças, mas milhares de militantes e simpatizantes de partidos de oposição ao governo foram presos. Nos primeiros meses de 1936 foi formada a Comissão Nacional de Repressão ao Comunismo e o estado de guerra foi instaurado. As prisōes ficaram abarrotadas, o navio Pedro I, ancorado nas docas do Rio de Janeiro, foi utilizado como cárcere, e a Colônia, que já era conhecida pelas condições precárias de habitação, passou a ter em torno de mil pessoas encarceradas, dobrando repentinamente sua lotação. Nesse período, os principais articuladores da Insurreição de 1935 foram violentamente torturados em quartéis da Polícia Especial e deixados na Casa de Correçáo, localizada no Catumbi, próxima do centro da cidade. Carlos Prestes e Harry Berger (Arthur Ewert), por exemplo, não foram enviados para a Ilha Grande. Para lá foram, contudo, mais de 400 presos acusados de participarem dos levantes comunistas, que se amontoavam com os presos que lá se encontravam. É importante destacar que, diferentemente do que acontecera alguns anos antes com as lideranças comunistas, os descontentes com o regime que eram encaminhados para Dois Rios eram colocados em galpóes comuns e com regalias muito pequenas.

Dois relatos desse período nos chegam aos dias atuais. Herondino Pereira Pinto, jornalista e sindicalista, preso entre 1935 e 1937, reuniu um conjunto de reportagens que havia escrito e as publicou através de uma editora anarquista, Germinal, por ocasião da candidatura de Getúlio Vargas à presidência, em 1950. Segundo o autor, a Colônia de Dois Rios era sinônimo de barbárie e morte. Lá os presos passavam fome, dormiam em um barracão cujo piso era de areia molhada, sobreviviam em condiçóes promíscuas e repugnantes, eram humilhados desde a formatura até a hora de dormir, estavam sujeitos a doenças como tuberculose, sendo também submetidos a trabalhos forçados e punições violentas. A aproximação que o autor fez entre Getúlio e Hitler certamente refletia não só estreitamento de laços entre Brasil e Alemanha, mas as péssimas condições da prisão. ${ }^{43}$

Graciliano Ramos foi preso em Alagoas, em 1936, e, após passar pela Casa de Detenção, foi transferido para a Colônia Correcional, onde ficou por 18 dias, entre 11 e 29 de junho. Ao ser preso não era membro do Partido Comunista do Brasil (PCB), partido a que se filiaria apenas em 1945. Também ainda não tinha escrito os livros que o fizeram conhecido pelo grande público. Não obstante, diversos intelectuais valorizavam seu trabalho, desde a publicação de Caetés, e, em sua libertação, contou com a campanha empreendida por José Lins do Rego e José Olympio, que denunciava a prisão arbitrária do escritor, sem qualquer processo formal. O livro Memórias do cárcere foi escrito em fascículos, entre 1945 e 1953, e deixado inconcluso por ocasião de sua morte. ${ }^{44}$

\footnotetext{
${ }^{43}$ PINTO, Herondino Pereira. Nos subterrâneos do Estado Novo. São Paulo: Germinal, 1950.

${ }^{44}$ Para uma análise da prisão de Graciliano Ramos, ver ANTONACI, Giovanna de Abreu. Os presos comunistas nos cárceres da Ilha Grande (1930-1945). Dissertação (mestrado em história) — Programa de Pós-Graduação em História, Universidade Federal Fluminense, Niterói, 2014; e ALVES, Fabio Cesar. Armas de papel:
} 
O relato de Graciliano é bem diferente daqueles deixados por Lima e Basbaum. Dedicou uma parte considerável de suas memórias à descrição das situaçôes indignas e humilhantes por que passara na Ilha Grande: a falta absurda de leitos, a comida que mais parecia um vômito, os seis chuveiros para mais de mil pessoas; as filas de homens cabisbaixos para chegarem aos poucos buracos transformados em latrinas. ${ }^{45}$ Segundo o autor, o ritual de entrada já anunciava as arbitrariedades que estavam por vir. Primeiro, os presos deixavam com os guardas todos os seus pertences e vestimentas, tinham suas cabeças raspadas, recebiam os uniformes "de zebra" e eram numerados. Em seguida, eram ameaçados por um dos guardas, que lhes dizia que não estavam lá para serem corrigidos, mas para morrer. ${ }^{46}$

As práticas prisionais descritas pelo escritor, como serem identificados por números, utilizarem vestimentas padronizadas e serem obrigados a uma obediência a normas irracionais, são inegavelmente práticas que têm por objetivo a despersonalização do indivíduo e o maior controle sobre ele. ${ }^{47}$ Além disso, os presos eram torturados e humilhados, tratados como bichos, amontoados em um curral de arame, obrigados a atividades físicas além de suas capacidades. O carregamento de vigas e tijolos era desumano. Havia quatro a seis chuveiros e o mesmo número de latrinas para novecentos indivíduos. A comida lhe parecia vômito e dormiam à noite em esteiras sobre o chão úmido. Sobre a violência, não poupou adjetivos:

Despertei, vi a dois passos um soldado cafuzo a sacudir violentamente o primeiro sujeito da fila vizinha. Muxicōes terríveis. A mão esquerda, segura à roupa de zebra, arrastou o paciente desconchavado, o punho direito malhou-o com fúria na cara e no peito. A fisionomia do agressor estampava cólera bestial; não me lembro de focinho tão repulsivo, espuma nos beiços grossos, os bugalhos duas postas de sangue. Os músculos rijos cresciam no exercício, mostrando imenso vigor. Presa e inerme, a vítima era um boneco a desconjuntar-se: nenhuma defesa, nem sequer o gesto maquinal de proteger alguma parte mais sensível. (...) O corpo estragado conservou-se imóvel. (.... ${ }^{48}$

Graciliano, ao ser colocado junto aos presos comuns, afastou-se dos militantes e misturou-se ao milheiro de homens que lá estavam sem processo, sem julgamento, sem direitos e ameaçados de morte desde o primeiro dia pelo guarda que os recebia. De maneira inversa, denunciou não a bestialidade dos presos, mas a violência dos guardas, estes sim apresentados como bestas humanas, ferozes e irracionais.

Graciliano Ramos, as Memórias do cárcere e o Partido Comunista Brasileiro. São Paulo: Editora 34, 2016.

${ }^{45}$ Para se ter ideia da situação calamitosa da Colônia em 1936, cujo número de presos passara de 298, em 1935, para 1.388, ver SANTOS, Myrian Sepúlveda. Os poróes da república: a barbárie nas prisôes da Ilha Grande (1894-1945), op. cit., p. 182-239.

${ }^{46}$ RAMOS, Graciliano. Memórias do cárcere. São Paulo: Livraria Martins Fontes Editora, p. 60-1, 1965, p. 63. v. 2.

${ }^{47}$ Sobre o tema, ver GOFFMAN, Erving. Manicômios, prisóes e conventos. São Paulo: Perspectiva, 1974.

${ }^{48}$ RAMOS, Graciliano. Memórias do cárcere, op. cit., p. 60-61. 
Todos em roda estavam assim, firmes, de braços cruzados, impassíveis. Nenhum sinal de protesto, ao menos de compaixão. Também me comportara com essa horrível indiferença, como se assistisse a uma cena comum. Éramos frangalhos; éramos fontes secas; éramos desgraçados egoísmos cheios de pavor. Tínhamo-nos reduzido a isso. Qual a razão daquela ferocidade? (...) Já nem me importava saber a causa da sevícia imprevista. Falta ligeira: algum descuido, gesto involuntário, cochicho a perturbar o silêncio. Estávamos reduzidos àquilo. ${ }^{49}$

O escritor se aproximou de Gaúcho, que se dizia ladrão e arrombador, e do negro Cubano, que fazia as chamadas e organizava as filas dos presos. Divertiu-se quando lhe disseram que utilizavam o Jornal do Brasil para recolher os vidros em um arrombamento, uma utilidade nova dada à imprensa. Admirou a franqueza e o heroísmo do sujeito absurdo e incongruente. Percebeu o cuidado de Cubano com ele e previu a formação de uma amizade duradoura com aquele "negro vagabundo". ${ }^{50}$ Graciliano teve curiosidade pelo mundo a que não pertencia, e, sem se afastar de si próprio, tornou-se próximo dos presos com quem dividiu seu espaço.

Apesar de dividir o galpão com presos comuns e ser submetido praticamente às mesmas condiçôes de precariedade e violência, Graciliano percebeu e denunciou a existência, ainda que diminuta, de um tratamento diferenciado por parte dos guardas e da direção. Ao ser convidado a escrever um discurso de elogio ao diretor, ele se negou, apesar de temeroso, e foi compreendido pelo guarda. Em outro episódio, diz ter se sentido ultrajado, quando chamado de doutor:

Doutor, que estupidez! Essa ironia besta anunciava desgraça. Tinha-me esforçado por esquivarme, ser uma partícula invisível na turba, linha de quatro algarismos no catálogo de Cubano. Obrigavam-me a sair da massa anônima, personalizavam-me e, além de tudo, conferiam-me distinção perigosa. Aquilo era tão burlesco e tão lastimoso que me senti como um ator infeliz chamado à cena para receber vaia. Tive a impressão de me haverem posto um rabo de papel $\mathrm{e}$ orelhas de burro. (...) Convenciam-se da existência de um doutor no meio ignóbil, a definhar na piolheira, o crânio devastado a máquina. ${ }^{51}$

$\mathrm{O}$ afastamento dos demais militantes trouxe problemas a Graciliano. Relatou que, em determinado momento, França, um companheiro, lhe disse que uma cama de ferro precária, que comprara de Gaúcho, para escapar das noites de insônia nas esteiras, deveria ser oferecida aos companheiros que estavam mais necessitados. Ele próprio, bastante doente, achou que aquela era uma demonstração de autoridade com base em ninharia. ${ }^{52}$

\footnotetext{
${ }^{49}$ Ibidem, p. 61.

${ }^{50}$ Ibidem, p. 96.

${ }^{51}$ Ibidem, p. 96-97.

${ }^{52}$ Ibidem, p. 113. Graciliano foi criticado por lideranças do PCB por prejudicar a visão que o partido estava construindo de si próprio. Agildo Barata, que conviveu com Graciliano na prisão, criticou o escritor por não
} 
Graciliano Ramos náo conheceu Caneppa, porque o diretor estava sendo substituído provisoriamente pelo médico Ouropretano Sardinha. Contudo, as críticas de Graciliano estavam direcionadas não só à figura do médico, mas à situação precária da instituição. Ao escrever sobre os dias que esteve na Colônia, a crueldade e irracionalidade do sistema ficaram expostas.

Em meados de 1937, o ministro da Justiça Macedo Soares foi responsável pela libertação de mais de quatrocentos presos políticos, que estavam detidos sem processo formado, em um episódio conhecido como "a macedada". Isso aconteceu poucos meses antes de ser decretado o estado de guerra. No ano seguinte, a vila Dois Rios, já sem os presos políticos, tornou-se um campo de obras voltado para a construção de uma penitenciária agrícola. Com o acirramento da oposição ao Estado Novo, lideranças comunistas, integralistas e liberais foram enviadas para a Penitenciária de Fernando de Noronha. Contudo, com a entrada do Brasil na Segunda Guerra Mundial, a penitenciária foi extinta e a ilha passou a ser utilizada para fins de defesa nacional. Em 1942, os presos políticos que lá estavam foram transferidos para a Colônia Agrícola do Distrito Federal (CADF), que passava a ser uma prisão de maior segurança. A Penitenciária Agrícola, que havia sido inaugurada há apenas quatro anos, para recuperação de presos de bom comportamento através do trabalho agrícola, e que mantinha subordinada a Colônia Correcional, foi transferida para outro polo da Ilha Grande, a Vila do Abraão, com o nome de Colônia Penal Cândido Mendes (CPCM).

Os presos políticos de Noronha, portanto, ao chegarem a Dois Rios encontraram na ilha instalaçôes novas e um número pequeno de presos. Segundo relatório de 1943, lá havia 240 condenados pela justiça comum e 290 presos políticos. ${ }^{53}$ Nos relatos deixados pelos militantes comunistas, entre eles, Agildo da Gama Barata Ribeiro, Carlos Marighella, Gregório Bezerra, e Joaquim Câmara Ferreira, encontramos muitas referências às reunióes e aos debates políticos. No relato deixado por Lauro Reginaldo da Rocha, a vida cotidiana na Ilha Grande aparece com mais detalhes. Alguns deles tinham trabalho parcialmente remunerado, moravam em casas com suas famílias e tinham liberdade de movimentaçáo pela vila. Pescavam e iam à praia. Recebiam notícias do exterior por meio de rádios, jornais e visitas. Segundo relatos de antigos moradores, o general Flores da Cunha, que fora interventor e governador eleito no Rio Grande do Sul, de 1930 a 1937, foi recebido pelo diretor com hasteamento da bandeira nacional. Ele tinha sua moradia e eram frequentes seus passeios pela regiáo. Belmiro Valverde, integralista e médico, também contou com as benesses do diretor. ${ }^{54}$ Mais uma vez ficou registrado que os presos políticos receberam atenção diferenciada da direção e dos guardas, que reconheciam os "doutores" e ofereciam favores. Nesses relatos, presos comuns

participar da vida dos presos políticos (ANTONACI, Giovanna de Abreu. Os presos comunistas nos cárceres da Ilha Grande (1930-1945), op. cit., p. 79).

${ }^{53}$ Arquivo Nacional. Fundo MJNI. Coleção Justiça. Notação IJ2-1279. Relatório do diretor da CADF ao MJNI, dez. 1943.

${ }^{54}$ Sobre o tema, ver SANTOS, Myrian Sepúlveda. A invisibilidade da pena: Dois Rios como imagem do paraíso. Tempo Social, v. 28, p. 261-283, 2016. 
aparecem apenas quando os militantes querem ressaltar a influência dos coletivos sobre eles, sem que a violência a que estivessem submetidos chegasse a ser uma questão. ${ }^{55}$

O historiador Marcos Bretas, ao analisar a literatura prisional, nos mostra que o prisioneiro tornou-se um "selvagem", vivendo no interior de uma cidade moderna e civilizada, segundo a construção de uma dupla natureza atribuída aos criminosos. Ainda, segundo ele, os escritores, em sua grande maioria, foram incapazes de decifrar esta construção. ${ }^{56} \mathrm{O}$ escritor Graciliano Ramos esteve preso no pior momento da Colônia, em 1936, quando o antigo prédio recebeu mais de mil presos. Ao ser jogado no meio dos presos comuns, ele fez registros distintos daqueles deixados pelos demais políticos da época, no sentido apontado pelo historiador Marcos Bretas; eles decifraram a falácia da dupla natureza. Publicadas em 1953, pela editora José Olympio, o livro Memórias do Cárcere teve enorme repercussão, tendo, uma após outra, suas ediçóes esgotadas. $\mathrm{O}$ escritor fez um relato detalhado do cotidiano das prisóes e descreveu pequenos infratores como indivíduos que têm seus erros e acertos, e com os quais podemos nos identificar.

\section{O "vagabundo" na cultura punitiva}

A Colônia Correcional de Dois Rios, que tivera por missão durante décadas a correção dos "vagabundos", tinha uma estrutura precária e fazia com que seus presos padecessem de todas as misérias e moléstias. Os presos que para lá eram enviados, além de pobres, não tinham acesso à lei, ou a qualquer outro mecanismo de denúncia sobre o tratamento que lhes era imposto, para que fossem respeitados. Ironicamente, foram os chamados "vagabundos" aqueles que tinham penas menores a cumprir, por terem cometido faltas menos graves, os que mais sofreram nas prisóes da Ilha Grande.

A Colônia Correcional começou a perder importância em 1938, quando ficou subordinada à Penitenciária Agrícola (PADF), ${ }^{57}$ um grande complexo penitenciário, construído para a correção, pelo trabalho agrícola, de presos que apresentavam bom comportamento. Apesar de a Lei das Contravençóes Penais, de 1941, estabelecer que os condenados por vadiagem e mendicância deveriam ocupar estabelecimentos especiais; eles, embora em menor número, continuaram a ser encaminhados para as colônias instaladas na Ilha Grande, convivendo com presos políticos e com indivíduos condenados por crimes diversos.

\footnotetext{
${ }^{55}$ Ver BARATA, Agildo. Vida de um revolucionário: memórias. São Paulo: Alfa-Omega, 1978; BEZERRA, Gregório. Memórias. Rio de Janeiro: Civilização Brasileira, 1980; e FERREIRA, Brasília Carlos (Org.). Lauro Reginaldo da Rocha, Bangu: memórias de um militante. Natal: Centro de Ciências Humanas, Letras e Artes, 1992.

${ }^{56}$ BRETAS, Marcos Luís. O que os olhos não veem: história das prisões do Rio de Janeiro. In: MAIA, Clarissa Nunes et al. História das prisóes no Brasil. Rio de Janeiro: Rocco, p. 185-213, 2009. v. 2.

${ }^{57}$ Criada através do Decreto-Lei no 319, de 7 de março de 1938.
} 
Com a saída de Caneppa da direção, José Jannini o substituiu com a missão de construir em Dois Rios uma Penitenciária Agrícola. O perfil da população carcerária modificou-se rapidamente, pois infratores de todos os tipos passaram a ser enviados para a Ilha Grande para serem utilizados como mão de obra. ${ }^{58}$ Apesar da mudança no perfil dos presos, continuaram as denúncias de espancamentos. A novidade foi a presença de processos que, embora arquivados quando chegavam ao Ministério da Justiça, eram abertos e tinham alguma repercussão na imprensa. Em março de 1939, por exemplo, o preso Sebastiáo da Silva denunciou as brutalidades a que eram submetidos quinhentos detentos, quase todos enviados à Colônia por ordem do chefe de polícia. Foram descritos o tratamento bárbaro e arbitrário, o trabalho forçado de carregamento de vigas, os castigos com coices de fuzil, os pontapés, os ferimentos e até mesmo mortes. ${ }^{59}$

Apesar das mudanças ocorridas em Dois Rios, e da perda de importância da Colônia e de sua proposta de correçáo de pequenos infratores, ${ }^{60}$ a Ilha Grande continuou a ser associada aos "vagabundos". Como mencionado, inicialmente, para o guarda penitenciário Inácio havia uma diferença entre os presos "valentes", que seriam aqueles mais perigosos e que eram enviados para Fernando de Noronha, e os "vagabundos", os pequenos infratores encarcerados na Ilha Grande.

Ao lembrar sua chegada na Ilha Grande, em 1951, e descrever suas atividades, ele se refere à maior parte dos presos como "vagabundos". Ressalta que, naquela época, o respeito aos guardas era muito grande e os castigos muito severos:

No refeitório cabiam 275 internos. (...) O respeito era grande. Ninguém podia falar nada, reclamar de nada. (...) Os guardas chamavam dois vagabundos e falavam: E aí, vagabundo? Fulano, fulano e fulano porque não tá limpo, direito? Se falasse muito, levava uma surra e ia pelado para uma cela durante trinta dias, porque tinha que estar tudo bem limpo, bem lavado. ${ }^{61}$

É interessante observar que quando Inácio chegou à ilha, em 1951, a Colônia Agrícola do Distrito Feral já não era a prisão dos contraventores, ou seja, dos pequenos infratores. Estes continuavam a ser presos, mas eram em grande parte encaminhados para a Colônia Penal, do outro lado da ilha. A população prisional a que Inácio se referia era constituída por indivíduos condenados por crimes como furto, assalto e até homicídio. ${ }^{62}$

\footnotetext{
${ }^{58}$ Sobre o tema, ver Ofício do diretor da PADF ao MJNI, 20 ago. 1940. Arquivo Nacional. Fundo MJNI. Coleção Justiça. Processo 15.327. Cx.788.

${ }^{59}$ Arquivo Nacional. Fundo MJNI. Coleção Justiça. Processo 2.757/39. Cx. 526. Carta do detento Sebastião da Silva, 6 mar. 1939, ao Corregedor do Distrito Federal.

${ }^{60}$ A Colônia Correcional de Dois Rios foi extinta formalmente a partir do Decreto-Lei no 2.601, 1ํ de maio de 1955.

${ }^{61}$ Trechos da entrevista realizada em outubro de 2010. Acervo do projeto de pesquisa Memória e violência na Ilha Grande, que, em seus desdobramentos, obteve apoio do CNPq, Uerj e FFLCH/USP.

${ }^{62}$ Arquivo Nacional. Fundo MJNI. Coleção Justiça. Processo 14.336. Cx. 4.057. Boletins de Serviço da CADF. 1951.
} 
Inácio tem uma memória exemplar e nos relata diversos casos do passado. Lembra-se, por exemplo, do roubo de cigarros de Dona Estefânia, uma velhinha que vendia bala, doces para crianças e caipirinha. Os ladróes foram espancados violentamente, tratamento que, segundo o guarda, era necessário para a manutenção da ordem e do respeito. A categoria de "vagabundo" não se associava mais à vadiagem ou ociosidade, mas àqueles que não obtinham o respeito dos guardas. Se o crime se associava à vadiagem, esse parecia ser um detalhe menor. $\mathrm{O}$ vadio ou vagabundo continuou a ser aquele que pode ser espancado, e, não por acaso, aquele que não tinha meios bastantes de subsistência, item ainda presente na Lei de Contravençóes Penais, em seu artigo 59.

$\mathrm{Na}$ década de 1940, portanto, houve mudanças importantes nas leis, nos estabelecimentos penais, que foram renovados, e no perfil da população prisional. Para guardas, policiais e para grande parte da população, as prisóes continuaram repletas de "vagabundos", indivíduos que poderiam ser presos, torturados e mortos.

Quando indagado o porquê da manutenção da violência nas prisóes da Ilha Grande, o guarda nos explica que não houve grandes mudanças no tratamento aos presos a partir das alteraçôes das leis porque os funcionários eram os mesmos:

Não mudou porque todos os funcionários eram os mesmos. A única coisa que mudava eram os diretores, porque deixava de ser diretor indicado pelo Ministro e passava a ser diretor indicado pelo Governador ou pelo Secretário de Justiça. ${ }^{63}$

Para os guardas, como para a população em geral, aquele que entra na prisão, seja baderneiro ou homicida, ganha o mesmo rótulo, o de "vagabundo". Nos dias atuais a antropologia criminal não é mais influente na formação de advogados e juristas e muitas alteraçôes foram realizadas no Código Penal que foi decretado em 1940. Continua, contudo, no sistema jurídico-penal a presença de uma zona cinzenta que articula o que é estipulado pela lei às práticas existentes nas prisóes. No caso analisado, observamos a importância da categoria "vagabundo" tanto para o julgamento como para o tratamento destinado a um indivíduo que entrava no sistema prisional.

Esse era um termo utilizado não apenas por parte dos guardas penitenciários; ele também fazia parte do vocabulário dos indivíduos encarcerados. A denominação de "vagabundo" legitimou, como ainda legitima, o tratamento diferenciado dos internos, independentemente do crime cometido e dos anos a cumprir em penas de privação de liberdade.

\footnotetext{
${ }^{63}$ Idem.
} 


\section{Fontes primárias}

\section{Leis}

Código Criminal de 1830

Código Penal de 1890

Decreto-Lei no 1.794 , de 11 setembro de 1894.

Decreto-Lei no 22.332, de 10 janeiro de 1933

Decreto-Lei no 319, de 7 março de 1938.

Decreto-Lei no 3.688 , de 3 outubro de 1941 .

Decreto-Lei no 2.601 , 1ํ de maio de 1955.

\section{Jornais}

A Ilha da Maldição, jornal $O$ Globo, 4 abr. 1934, p. 1-2.

\section{Documentos oficiais}

Arquivo Nacional. Biblioteca. Código 3789: 1181. Comunicado do diretor da Colônia Victorio Caneppa ao Chefe de Polícia Filinto Müller. 10 jan. 1936.

Arquivo Nacional. Fundo MJNI. Coleçâo Justiça. Notação IJ2-1279. Relatório do diretor da CADF ao MJNI, dez. 1943.

Arquivo Nacional. Fundo MJNI. Coleção Justiça. Processo 14.336/51. Cx. 4.057. Boletins de Serviço da CADF. 1951.

Arquivo Nacional. Fundo MJNI. Coleção Justiça. Processo 15.327/40. Cx. 788. Ofício do diretor da PADF ao MJNI, 20 ago. 1940.

Arquivo Nacional. Fundo MJNI. Coleção Justiça. Processo 2.757/39. Cx. 526. Carta do detento Sebastião da Silva, 6 mar. 1939, ao Corregedor do Distrito Federal.

Arquivo Nacional. Fundo MJNI. Coleção Justiça. Processo 362/36. Cx. 69. Carta do Deputado João Café Filho, 1936, para que sejam averiguadas as condições de tratamento dadas aos presos políticos.

Arquivo Nacional. Fundo MJNI. Coleção Justiça. Projeto de Construção da Colônia Penal Agrícola da Ilha Grande, 16 out. 1936. Processo 137/36. Cx. 846.

Relatório do Ministro de Justiça, Dr. Rivadávia da Cunha Corrêa, ao Presidente da República, relativo aos anos 1912 e 1913. Disponível em: <http://brazil.crl.edu/bsd/bsd/ u1909/000001.html>. Acesso em: 20 jul. 2016. 


\section{Referências bibliográficas}

AGUIRRE, Carlos; SALVATORE, Ricardo D. Writing the Historyof Law, Crime, and Punishment in Latin America. In: SALVATORE, Ricardo D.; AGUIRRE, Carlos; JOSEPH, Gilbert M. (Eds). Crime and Punishment in Latin America. Durham, Londres: Duke University Press, 2001, p. 1-32.

ALVAREZ, Marcos César. Bacharéis, criminologistas e juristas: saber jurídico e a nova escola penal no Brasil (1889-1930). São Paulo: USP/FFLCH, 1996.

. A criminologia no Brasil ou como tratar desigualmente os desiguais. Dados Revista de Ciências Sociais, v. 45, n. 4, p. 677-704, 2002.

ALVES, Fabio Cesar. Armas de papel: Graciliano Ramos, as memórias do cárcere e o Partido Comunista Brasileiro. São Paulo: Editora 34, 2016.

ANTONACI, Giovanna de Abreu. Os presos comunistas nos cárceres da Ilha Grande (19301945). Dissertação (Mestrado em História) — Programa de Pós-Graduação em História, Universidade Federal Fluminense, Niterói, 2014.

BARATA, Agildo. Vida de um revolucionário: memórias. São Paulo: Alfa-Omega, 1978.

BASBAUM, Leôncio. Uma vida em seis tempos. São Paulo: Alfa-Omega, 1976.

BEZERRA, Gregório. Memórias. Rio de Janeiro: Civilização Brasileira, 1980.

BRETAS, Marcos Luís. Ordem na cidade: o exercício cotidiano da autoridade policial no Rio de Janeiro, 1907-1930. Rio de Janeiro: Rocco, 1997.

. O que os olhos não veem: história das prisões do Rio de Janeiro. In: MAIA, Clarissa Nunes et al. História das prisóes no Brasil. Rio de Janeiro: Rocco, p. 185-213, 2009. v. 2.

CANCELLI, Elizabeth. O mundo da violência - a polícia da era Vargas. Brasília: Editora UnB, 1994.

CHALHOUB, Sidney. Trabalho, lar e botequim. O cotidiano dos trabalhadores no Rio de Janeiro da Belle Epoque. São Paulo: Brasiliense, 1986.

COELHO, Edmundo Campos. A oficina do diabo. Crise e conflito no sistema penitenciário do Rio de Janeiro. Rio de Janeiro: Iuperj, 1987.

CORRÊA, Mariza. As ilusóes da liberdade: a escola Nina Rodrigues e a antropologia no Brasil. Bragança Paulista: EDUSF, 1998.

ENGEL, Magali Gouveia. Os delírios da razão: médicos, loucos e hospícios (Rio de Janeiro, 1830-1930). Rio de Janeiro: Editora Fiocruz, 2001.

FERREIRA, Brasília Carlos (Org.). Lauro Reginaldo da Rocha, Bangu: memórias de um militante. Natal: Centro de Ciências Humanas, Letras e Artes, 1992.

FOUCAULT, Michel. Vigiar e punir: nascimento da prisão. Petrópolis: Vozes, 1987. 
. A ordem do discurso. São Paulo: Edições Loyola, 1996.

FRY, Peter; CARRARA, Sérgio Luis. As vicissitudes do liberalismo no direito penal brasileiro. Revista Brasileira de Ciências Sociais, v. 1, n. 2, p. 48-54, 1986.

GOFFMAN, Erving. Manicômios, prisóes e conventos. São Paulo: Perspectiva, 1974.

HOLLOWAY, Thomas H. Policing Rio de Janeiro. Repression and resistance in a $19^{\text {th }}$ century city. Albuquerque: University of New Mexico, 1993.

LIMA, Heitor Ferreira. Caminhos percorridos: memórias de militância. São Paulo: Brasiliense, 1982.

LOMBROSO, Cesare. O homem delinquente. Porto Alegre: Ricardo Lenz, 2001.

PEDROSO, Regina Célia. Os signos da opressão. História e violência nas prisôes do Brasil. São Paulo: Arquivo do Estado/Imprensa Oficial do Estado, 2003.

PINTO, Herondino Pereira. Nos subterrâneos do Estado Novo. São Paulo: Germinal, 1950.

QUEIROZ, Rafael Mafei Rabelo. A modernização do direito penal brasileiro: sursis, livramento condicional e outras reformas do sistema de penas clássico no Brasil, 1924-1940. São Paulo: Quartier Latin do Brasil, 2007.

RAMOS, Graciliano. Memórias do cárcere. São Paulo: Livraria Martins Fontes Editora, 1965. v. 2.

RODRIGUES, Nina. As raças humanas e a responsabilidade penal no Brasil. São Paulo: Companhia Editora Nacional, 1938.

SALLA, Fernando. As prisóes em São Paulo:1822-1940. São Paulo: Annablume, 1999.

SANTOS, Myrian Sepúlveda. Os porôes da República: a barbárie nas prisões da Ilha Grande (1894-1945). Rio de Janeiro: Eduerj/Garamond, 2009.

. A invisibilidade da pena: Dois Rios como imagem do paraíso. Tempo Social, v. 28, p. 261-283, 2016.

VIANNA, Adriana de Resende Barreto. O mal que se advinha: polícia e menoridade no Rio de Janeiro, 1910-1920. Rio de Janeiro: Arquivo Nacional, 1999. 